\title{
The effect of diet on fat cell metabolism. A review
}

\author{
Katarzyna Kandulska and T. Szkudelski \\ Department of Animal Physiology and Biochemistry, \\ Poznań Universitv of Agriculture. \\ Wolyńska 35, 60-637 Poznań, Poland
}

(Received 4 May 1998; accepted 24 Junc 1998)

\begin{abstract}
A bricf revicw of processes occurring in fat cells is given and the regulatory effects of certain hormones and nutrients are presented.

Fat cells are found in the white adipose tissue and store substantial amounts of triglyceridcs. The process through which triglycerides are formed in these cells is called lipogenesis and is stimulated by insulin. The opposite process, lipolysis, i.e. the degradation of triglyccrides with the liberation of glycerol and free fatty acids into the circulation, is stimulated by glucagon and adrenaline. Many factors related to mutrition such as, for example, fasting, nutritional status, the carbohydrate level of the diet, amount and composition of fats in it, can modify these processes. The diet and its composition also have an important ellect on brown adipose tissue.
\end{abstract}

KEY WORDS: adipose tissuc, metabolism, hormones, nutrition

\section{INTRODUCTION}

In contrast to carbohydrates, lipids can be stored in the body in substantial amounts that suffice to cover its energy needs for a long time after the lipids have been absorbed. Their main reservoir is white adipose tissue. The cells of this tissue are called fat cells and are able to store large amounts of fat in the form of triglycerides. This is fat taken up from the plasma or synthesized in these cells, mainly from glucose. However, when the body experiences an energy deficit, triglycerides stored in fat cells are casily mobilized and serve as a source of energy for numerous other types of cells. 
Appropriate regulation of fat cell function is necessary to maintain the proper balance between lipogenesis and lipolysis, which affects the organism's entire energy metabolism. Moreover, disorders in fat cell function resulting from various causes, cspecially those leading to the deposition of excessive amounts of adipose tissue, lead to many serious diseases ( Jeppesen et al., 1995). For these reasons, elucidating the processes occurring the cells of white adipose tissue and determining the factors that affect them is important not only from the scientific, but also from the practical point of view.

Studies on the metabolism of fat cells became possible thanks chiefly to the work of Rodbell (1964). The method of isolating these cells developed by this researcher are still widely used today with only a few minor modifications. This method makes it possible to obtain from a variety of animals species a large number of fat cells that react to numerous physiological and pharmacological factors. This creates a wide spectrum of in vitro experimental possibilities.

Thanks to many researchers, lipolysis and lipogenesis in white adipose tissue are now relatively well understood. It has also been possible to show that many factors, including some in the diet, have a distinct effect on them. In this paper we present some of these factors.

General characteristics of processes occurring in fat cells

Lipogenesis is one of the processes that take place in fat cells. The substrates for the synthesis of triglycerides in the fat cell are triglycerides in the blood stream, mainly in the chylomicrons and very low density lipoproteins VLDL. They must be broken down into glycerol and free fatty acids before they enter the cell. This reaction is catalyzed by the lipoprotein lipase synthesized and excreted by fat cells (Eckel, 1987). On the basis of work by Rodbell (1964) it is also known that glucose is converted into glycerol and fatty acids in the cells of white adipose tissue. These compounds are then used to synthesize triglycerides. The second important metabolic pathway into which glucose is channeled is its oxidation to $\mathrm{CO}_{2}$ (Rodbell, 1964). Of course, before any of these processes can take place, glucose must first find its way into the cell, and this is also subject to regulation.

In addition to lipogenesis, a second important process that occurs in white adipose tissue cells is lipolysis. The intensity of the breakdown of triglycerides in these cells is to a large extent dependent on the formation of cyclic adenosine monophosphate (cAMP) (Amstrong ct al., 1974; Beebe et al., 1985; Perea et al., 1995). Under physiological conditions, this nucleotide arises mainly as the result of stimulation of adrenergic receptors (Langin et. al., 1992) or in response to glucagon (Perea et al., 1995). cAMP is a second messenger that participates in the transfer of signals in the cell and is synthesized from adenosine triphosphate in 
a reaction catalyzed by adenylate cyclase (Butcher et al.,1968; Rodbell et al., 1968). A rise in the cAMP concentration in fat cells activates protein kinase A (Langin et. al., 1992) which then catalyses the phosphorylation (activation) of hormone-sensitive lipase (HSL) (Belfrage et al., 1981). This lipase is an extremely important cnzymc in lipolysis since it catalyses the degradation of triglycerides (Belfrage et al., 1984).

In brief, the degradation of triglycerides is preceded by an entire cascade of reactions beginning from the action of a factor increasing the amount of cAMP in fat cells, ending with the liberation of glycerol and free fatty acids by cells (Lefcbvre, 1975; Perea, 1995). Decreasing the amount of cAMP in fat cells as the result of its degradation by the appropriate phosphodiesterase inhibits lipolysis (Beebe ct al., 1985; Eriksson et al., 1995).

\section{Hormonal regulation}

Under physiological condition, the most important element of the complex regulation of the processes occurring in fat cells is the endocrine system. Among the many hormones, insulin, glucagon and adrenaline are particularly important.

The effect of insulin in preceded by its association with $\alpha$-subunits of a specific receptor in the cell membrane. This causes changes in conformation of the receptor, as the result of which its transmembrane $\beta$-subunits gain tyrosine kinase activity (Tornqvist et al., 1987). In effect, autophosphorylation of these subunits occurs, followed by the phosphorylation of cytoplasmic substrates; the signal carried by the hormone reaches the cell interior (Rosen,1987).

It was found that insulin has strong anti-lipolytic activity (Mersmann,1986). This hormone stimulates the phosphorylation of phosphodiesterase catalyzing the degradation of cAMP. In rat fat cells, the activation of phosphodiesterase by insulin occurs as the result of phosphorylation of amino acid 302, serine, in the enzyme molecule (Degerman et al., 1998). The reversible phosphorylation of this amino acid is an element of the reverse feed back mechanism of the system controlling lipolysis. It was found that not only insulin, but other factors that stimulate lipolysis through increasing the concentration of cAMP lead to the phosphorylation of serine 302 in the phosphodiesterase molecule. This effect is probably mediated by the $\mathrm{c} \Lambda \mathrm{MP}$-dependent protein kinase (protein kinase $\Lambda$ ) (Degerman et al., 1998). Phosphorylation of phosphodiesterase activates it (Degerman et al., 1990) and, as a consequence, leads to the reduction of the amount of cAMP in the cells and to the inactivation of protein kinase $\Lambda$ (Degerman et al., 1998). This is necessary and sufficient for the anti-lipolytic effect of insulin to be manifested (Eriksson et al., 1995) (Diagram 1). Changes in the activity of the enzyme directly catalyzing lipolysis, hormone-sensitive lipase, are regulated by the appropriate hormones also through reversible phosphorylation. Hormones having lipolytic effects 
catalyze the phosphorylation of the regulatory site in the lipase molecule, while insulin or $\beta$-adrenergic antagonists lead to the opposite effect (Stralfors et al., 1984). It has been shown that the amino acid that undergoes phosphorylation is serine (Groscolas and Herzberg, 1997).

An important consequence of the action of insulin on fat cells is an increase in the transport of glucose into cells (May and Mikulecky, 1983; Akanbi et al., 1990) which makes it possible for this sugar to be metabolized. The transport of glucose into cells is mediated by specialized proteins (Pedersen et al., 1991). These proteins, in response to insulin, move from the cytoplasm to the cell membrane and transport glucose across it. Insulin also markedly intensifies the processing of glucose into free fatty acids and glycerol in fat cells (Rodbell, 1964). These effects stimulate lipogenesis. In addition, insulin distinctly increases the processing of glucose into $\mathrm{CO}_{2}$ (Rodbell,1964).

Glucagon is an antagonist of insulin. The effect of glucagon on its membrane receptor activates adenylate cyclase and starts the cascade described above leading to lipolysis. In response to glucagon, the amount of glycerol and free fatty acids liberated by cells increases (Perea et al., 1995). Adrenaline has a similar effect. As the result of this hormone stimulating $\beta$-adrenergic receptors (Langin et al., 1992), protein Gs in fat cells is activated. In turn, it activates adenylate cyclase.

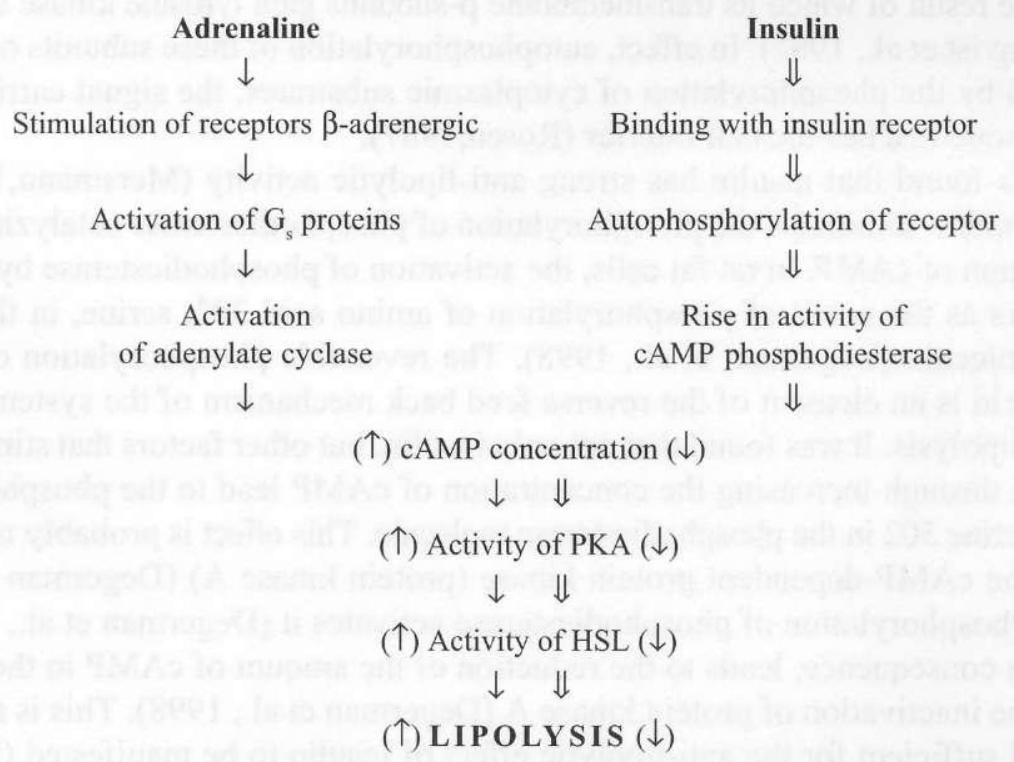

Diagram 1. Mechanism of lipolytic action of adrenaline and inhibitory effect of insulin $\downarrow$-adrenaline pathway, $\downarrow$ - insulin pathway; $(\uparrow)$ - rise, $(\downarrow)$ - decrease; PKA - protein kinase A, HSL - hormone sensitive lipase 
The formation of cAMP leads to the activation of protein kinase A, which then activates hormone sensitive lipasc (Gries et al., 1972; Belfrage et al., 1981; Tebar et al., 1996) (Diagram 1 ).

The effect of dict

It has been known for a long time that the diet and its composition have a very important effect on the entire organism, including fat cells. Particularly important are changes in the concentrations and effects of hormones that occur during fasting and absorption in response to various compounds absorbed from food. Changes in the insulin:glucagon ratio, as well as changes in the concentrations of some other hormones have, among others, a role in adapting the organism to processing and storing excess nutrients absorbed from the gastrointestinal tract or, after completion of the absorption phase, cause substrates used by cells to be releases into the blood stream.

The adipose tissue plays a very important role in the storage and release of energy substrates.

Changes in the amount of food consumed cause interesting changes in white adipose tissuc. In rats deprived of food for $48 \mathrm{~h}$ or longer, the volume of cells decreases. Their size returns to values observed in control animals only after several days of normal feeding (Owens et al., 1979; Fried et al., 1983). This is accompanicd by fluctuations in the activity of lipoprotein lipase within the adipose tissue. During fasting the activity of this enzyme decreases considerably. After resumption of normal feeding, its activity returns to normal values after 3-5 days, and then can be significantly elevated for the next few days in comparison with the basal value from before the fasting - this is the so-called overshoot effect. At the same time, the volume of fat cells increases (Fried et al., 1983). When, however, feeding is restricted after the period of fasting (by $25 \%$ or more), the rise in lipoprotein lipase activity is lower (Fried et al., 1983). The level of feeding after the end of fasting in animals has, therefore, a marked effect on the rate at which lipids accumulate in fat cells and the related "making up for losses" caused by fasting. It was also found that in vitro fat cells obtained from fasting animals show a diminished response to insulin. In these cells the metabolism of glucose into free fatty acids and its catabolism into $\mathrm{CO}_{2}$ are reduced (Owens et al., 1979; Timmers and Knittle, 1980; Casanova et al., 1990). The limitation of the metabolism of glucose into fatty acids may also be the effect of reduced expression of the gene for fatty acid synthase that occurs during fasting. Resumption of normal feeding normalizes this process (Kim ct al., 1998). The conversion of glucose into glycerol in fat cells obtained from animals subjected to fasting can be slightly reduced (Owens et al., 1979) or increased (Casanova et al., 1990). It is also known that 
fasting lowers the activity of numerous enzymes participating in the metabolism of glucose in the presence of insulin (Timmers and Knittle, 1980) or in the absence of this hormone in the incubation medium (Owens et al., 1979). Restricting the metabolism of glucose by fat cells that occurs during fasting is undoubtedly a defense mechanism. This ensures a greater supply of glucose for those cells for which this sugar is a crucial energy substrate, e.g. brain cells, erythrocytes.

The nutritional status of an organism also has an effect on the reaction of fat cells to adrenalinc. It was observed that cclls obtained from rats that had been subjected to fasting for two days showed a higher adenylate cyclase activity in response to adrenaline (Gorman et al., 1972). Fasting also causes a rise in the cAMP concentration and an increase in the activity of the protein kinase dependent on this nucleotide (Ruiz et al., 1981). In experiments on rats it was found that long-term malnutrition (a $60 \%$ deficit) partially reduces the decreasing fat cell sensitivity to catecholamines observed with age (Yu et al.,1980). The nutritional status of an organism can also indirectly modify the reaction of these cells to catecholamines. A rise in the concentration of insulin in the absorption phase reduces the amount of $\mathrm{mRN} \Lambda$ of the $\beta_{3}$-adrenergic receptor that plays a key role in the action of catecholamines on cells in the adipose tissue. Insulin indirectly restricts the expression of the adrenergic receptor gene and reduces the activity of adenylate cyclase in response to the action of agonists of this receptor (Hadri et al., 1997).

Feeding animals a diet containing excess energy supplied in the form of carbohydrates also is not without effect on adipose tissue. The degree of changes is, however, dependent on the duration of feeding the animals the high carbohydrate diet. Short term (5 days) feeding of rats with a feed containing glucose may increase the binding of insulin by fat cells and increases the oxidation of this sugar in cells. After the next few days, the course of these processes may nonnalize (Oka et al., 1980). A higher carbohydrate content in the dict of rats may, after a longer time, reduce insulin binding by cells of this tissue and intensify intracellular degradation of the hormone. Despite this, the uptake of glucose by fat cells may by clevated (Olefsky and Seakow, 1978). Glucose is then converted to a greater degree to triglycerides (Olefsky and Seakow, 1978). In experiments using fat cells from young pigs, it was shown that feeding these animals feeds with the addition of maize starch caused a distinct rise in lipogenesis stimulated by insulin (Smith et al., 1996). It was also observed that excess energy in food may contribute to a reduction in the amount of cAMP and restriction of lipolysis in fat cells (Kenan et al., 1997).

Lipids that reach the fat cells through the blood stream are another factor that modifies the course of several of processes in these cells. Increasing the fat level of a diet distinctly inhibits the de novo synthesis of fatty acids in fat cells obtained from growing pigs (Allee et al., 1971; Mersmann ct al., 1984; Benmansour ct al., 
1991 ) and rats (Smith et al., 1974; Lavau at al., 1979). This seems to result from the fact that a high dietary fat content markedly restricts the uptake of glucose by fat cells (Ip et al., 1977; Olefsky and Seakow 1978; Pedersen et al., 1991; Sevilla et al., 1997). The maximum transportation speed of this sugar is, as a result, reduced (Olefsky and Seakow 1978). Deterioration of the transport of glucose into cells appears as the result of a drastic reduction of the number of glucose transporters in ccll membranes. In rats fed a feed with a high fat content, the insulinstimulated transport of glucose into fat cells was found to have markedly decreased. These changes were accompanied by a distinct decrease in the expression of genes coding for the proteins that transport glucose through the cell membrane (Pedersen et al., 1991). Also the amount of these proteins (Glut 4 and Glut 1) in the cell was substantially decreased (Pedersen et al., 1991; Sevilla et al., 1997). The cause of the above changes is a decline in insulin binding by fat cells from animals fed high fat dicts (Ip et al., 1977; Olefsky and Seakow, 1978) and increased degradation of this hormone in these cells (Olefsky and Seakow, 1978). Moreover, it was found that feeding animals feeds with an increased fat content may lower the activity of tyrosine kinase of the insulin receptor in fat cells (Watarani at al., 1988) weakening the action of this homone. A consequence of excessive dietary fat is also a decline in the activity of some enzymes in adipose tissue, restricting the oxidation of glucose to $\mathrm{CO}_{2}$ (Allec et al., 1972).

It was found that lowering body weight and lowering the fat content of the diet can normalize the above disorders and restore normal cellular sensitivity to insulin (Salans and Dougherty, 1971).

An clevated dietary fat content may also reduce the sensitivity of fat cells to adrenaline (Gorman et al., 1972; Smith et al., 1974) and glucagon (Gorman et al., 1972), which leads to a fall in lipolysis.

On the basis of many studics it is known that not only the amount of fat in the dict, but also its type play an important role. It seems that although in the case of a high dietary fat content unfavourable effects are observed regardless of the type of fat (Allce ct al., 1972), in the case of a normal supply of this component, it has, depending on the type, a clearly differentiated effect. In experiments using fat cells from rats fed for 4 weeks with a feed containing various proportions of saturated and polyunsaturated fatty acids (PUFA), considerable differences were demonstrated in the responses of cells to adrenaline. A diet with a high PUFA content caused a distinctly higher sensitivity of fat cells to this hormone (Awad and Chattopadhyay, 1986). Changes such as this were observed even in adult sheep, but they were less pronounced than in monogastric animals. (Jenkins et al., 1994). On the other hand, a high level of unsaturated fatty acids in the diet was the cause of a significant reduction in the lipolytic activity of adrenaline (Awad and Chattopadhyay, 1986). Changes characteristic of the action of adrenaline, e.g. a rise in the activity of hormone-dependent adenylate cyclase and lipase, and the accumulation 
of cAMP were much less pronounced in response to this hormone in fat cells from rats fed diets with a high proportion of saturated fatty acids ( $\Lambda$ wad and Chattopadhyay, 1986). The beneficial effects of PUFA in the diet were also obscrved in respect to insulin. It was found that a higher proportion of these acids in the diet increases the capacity of cellular insulin receptors (the number of sites binding the hormone) (Field et al., 1988), increases the binding of insulin by fat cells (Field et al., 1988, 1989) and intensifies their response to this hormone (Van Amelsvoort et al., 1988). After insulin stimulation of fat cells from animals fed PUFA-enriched feeds, greater transport of glucose into cells, as well as increased oxidation and conversion of glucose into lipids are obscrved (Ficld et al., 1990; Luo et al., 1996). Feeding rats feeds with PUFA causes a rise in the content of these acids in fat cell membrane phospholipids (Field et al., 1988, 1990; Luo et al., 1996). Moreover, this causes a rise in the ratio of phosphatidylcholine to sphingomyelin and makes the cell membranes more fluid (Parrish et al., 1997). At the same time, other in vitro experiments showed increased insulin binding by cells with higher proportions of PUFA in their membranes (Gould et al., 1982). In experiments on pig fat cells, it was found that not only the degree of saturation of fatty acids in the diet, but also their chain length had a significant effect on the effectiveness of insulin (Smith et al., 1996). Not without meaning is the position of the double bonds in fatty acids (Fickova et al., 1998). There are, however, also reports in which no direct effect of the addition of sunflower oil to the feed of fattening pigs on lipogenesis or insulin binding by fat cells was found (Benmansour et al., 1991). This may be the result of other factors found in the diet. The effects of diets on processes in the cells of white adipose tissuc are compared in Table 1.

Interesting discoveries have been made in recent years, casting new light on the role of fat cells. It was found that the adipose tissue cells play an important role not only as passive stores of fat, but that they actively participate in regulating the body's energy balance. This is done through leptin, a protein synthesized and excreted only by fat cells (Maffei et al.,1995a). Leptin is a product of the $o b$ gene and its action is related to the maintenance of body weight, particularly to regulating its fat content (Maffei et al.,1995b). Insulin plays a prominent role among the many factors that regulate the expression of the $o b$ gene and the production and release of leptin (Saladin et al., 1995; Kim et al., 1998). Plasma concentrations of leptin, insulin and glucose decline during fasting and rise after cating. It was shown in vitro that incubation of fat cells in a medium containing insulin causes the release of leptin in amounts proportional to the concentration of insulin (Gettys et al., 1996). Insulin is not directly responsible for the increased secretion of leptin. The secretion of leptin is also dependent on the transport of glucose into fat cells and its metabolism there (Mueller et al., 1998). Both processes are, however, stimulated by insulin. A rise in the concentration of cAMP in fat cells during lipolysis results in a reduction in the synthesis and excretion of leptin (Slieker et al., 1996). It was 
TABLE 1

Effect of diet on some processes in fat cells

\begin{tabular}{|c|c|c|}
\hline Factor & Changes & Nuthors \\
\hline Fasting & $\begin{array}{l}\text { Reduction of fat cell volume } \\
\text { Restriction of lipogencsis } \\
\text { Decrease of lipoproteinase lipase activity } \\
\text { Increase of adenylate cyclase activity } \\
\text { after stimulation with adrenaline } \\
\text { rise in cAMP concentration and } \\
\text { rise in activity of cAMP-dependent protein } \\
\text { kinase restriction of expression of ob gene } \\
\text { and lower leptin secretion }\end{array}$ & $\begin{array}{l}\text { Fried et al., } 1983 \\
\text { Casanova et al., } 1990 \\
\text { Fricd ct al., } 1983 \\
\text { Gorman et al., } 1972 \\
\text { Ruiz et al., } 1981 \\
\text { Kim et al., } 1998 \\
\text { Frederich et al., } 1995 \mathrm{~b}\end{array}$ \\
\hline High-energy diet & $\begin{array}{l}\text { incrcased lipogcnesis Smith et al., } 1996 \\
\text { restricted lipolysis Kenan et al., } 1997\end{array}$ & \\
\hline High-fat diet & $\begin{array}{l}\text { inhibition of fatty acid synthesis } \\
\text { reduced glucose uptake } \\
\text { and lower expression } \\
\text { of genes coding for glucose transport protcins } \\
\text { and lower amount of these proteins } \\
\text { reduced insulin binding } \\
\text { lower tyrosine kinase activity of insulin } \\
\text { receptor } \\
\text { increased secretion of leptin }\end{array}$ & $\begin{array}{l}\text { Olefsky and Seakow } 1978 \\
\text { Watarani et al., } 1988 \\
\text { Frederich et al., } 1995 \mathrm{a}\end{array}$ \\
\hline \multirow{2}{*}{\multicolumn{2}{|c|}{$\begin{array}{ll}\text { Increasing amountincreased scnsitivity to adrenaline } \\
\text { of unsaturated } & \text { (higher rise of adenylate cyclase } \\
\text { fatty acids } & \text { and hormone sensitive lipase activities } \\
\text { in diet } & \text { and greater accumulation of } \\
& \text { cAMP after stimulation with adrenalin) }\end{array}$}} & Awad and Chattopadhyay, 1986 \\
\hline & & $\begin{array}{l}\text { Field et al., } 1988 \\
\text { Van Amelsvoort et al., } 1988 \\
\text { Field et al., } 1990 \\
\text { Luo et al., } 1996 \\
\text { Field et al., } 1990 \\
\text { Luo et al., } 1996\end{array}$ \\
\hline
\end{tabular}


found that secretion of leptin stimulated by insulin is inhibited as the result of a rise in the activity of cAMP-dependent protein kinase. Various compounds cau$\operatorname{sing} \beta_{3}$-adrenergic activation can inhibit the secretion of lcptin by fat cells (Gettys et al., 1996). Stimulation of $\beta_{3}$-adrenergic receptors therefore plays an important role in inhibiting the secretion of leptin. The type of diet also has a distinct effect on the secretion of this hormone. Feeding animals feeds with elevated fat contents can intensify the secretion of leptin (Frederich et al., 1995a). Fasting and weight loss reduce its plasma concentration (Frederich et al., 1995b). On the basis of the most recent reports, it is known that the expression of the leptin gene is regulated by the appropriate transcription factors, whose activity is markedly reduced during fasting and rises when feeding is resumed (Kim et al., 1998). At present it is known that leptin acts, among others, on the central nervous system regulating food intake and energy utilization (Wilding et al., 1993; Stephens et al., 1995). This hormone has an anorectic effect (Campfield ct al., 1995), and its deficiency may lead to hyperphagia. In obese mice it normalized body weight and lowers plasma glucose and insulin concentrations (Stephens ct al., 1995). It is presumed that some of the effects of leptin on the central nervous system may be related to its inhibitory effect on the gene coding neuropeptide Y (one of the important factors responsible for body weight gain, increased appetite and reduction of thermogenesis in brown adipose tissuc) (Stephens et al.,1995; Wang et al., 1997). The systemic effects of leptin manifest themselves, among others, through its effect on fat cells. This hormone visibly reduces the response of these cells to insulin. It weakens the stimulatory effect of insulin on glucose transport and lipogenesis, and reduces the inhibitory effect of insulin on protein kinase A activity and lipogenesis induced by isoprotenerol (Muller et al., 1997). The degree of its activity depends on the concentration of leptin and this effect is reversible (Muller et al.,1997). It was found that leptin decreases the effect of insulin on fat cells by reducing the binding of the hormone with the insulin receptor, but does not cause a change in affinity (Walder et al., 1997), which shows that leptin acts by reducing the binding capacity of receptors.

When discussing white adipose tissue one can not overlook the tissue called the brown adipose tissue. Its main role is the production of heat in nonshivering thermogenesis. This process is possible thanks to the presence of an uncoupling protein in the mitochondria. This protein uncouples oxidative phosphorylation, leading to the production of heat (Champigny and Ricquier, 1990). The results of numerous studies provide a considerable body of evidence that the diet and its composition have a clear effect on processes occurring in brown adipose tissue.

Starving rats for $24 \mathrm{~h}$ slows down mitochondrial processes and restricts the expression of the gene coding for the uncoupling protein. This is accompanied by a decline in the amount of this protein in the mitochondria (Matamala et al., 1996). These changes also depend on the temperature of the environment (Champigny and Ricquier, 1990). Fasting for several days results in the loss of fatty acids from 
triglycerides and phospholipids accumulated in brown adipose cells. This leads to changes in the composition of fatty acids in the cell membranes of this tissue since mobilization of linolenic acid from triglycerides and n-6 fatty acids from phospholipids takes place much more slowly (Groscolas and Herzberg, 1997). Fasting also leads to a fall in the activity of enzymes involved in lipogenesis. After the end of fasting, a considerable rise in their activity to levels exceeding baseline is observed, i.e. the overshoot effect is observed. Supplying sugars in drinking water prevents the fall in enzyme activity (Boll et al., 1996).

In rats fed a high carbohydrate dict were found to have an elevated body temperature. Intensification of thermogenesis occurred mainly through the hyperplasia of brown adipose tissue (Moriya, 1994). Oxygen consumption was also higher, and the amount of triglycerides and phospholipids in the brown adipose tissue was also raised. The share of unsaturated fatty acids in triglycerides and phospholipids may also increase (Moriya, 1994). A high energy dict causes a rise in the activity of adenylate cyclase in the cells of yellow and brown adipose tissues (Kenan et al., 1992). It is also known that unsaturated fatty acids in food lower diet-induced thermogenesis in comparison with diets containing PUFA from the n-3 family (Matsuo et al., 1995; Oudart et al., 1997). Chemical sympathectomy (blocking the sympathetic nervous system) eliminates these differences (Matsuo et al., 1995).

The evidence in the literature clearly shows that the diet has a significant effect on processes occurring the white and brown adipose tissue cells. This occurs through changes in hormone concentrations, as well as through quantitative and qualitative differences in the substrates reaching these cells.

\section{REFERENCES}

Akanbi K.A., England D.C., Hu C.Y.,1990. Effect of insulin and adrenergic agonists on glucose transport of porcine adipocytes. Comp. Biochem. Physiol. 97C, 133-138

Allee G.L., O'H lea F.K., Leveile G.A., Baker D.H.,1971. Influence of dietary protein and fat on lipogenesis and enzymatic activity in pig adipose tissue. J. Nutr. 101, 869-875

Allec G.L., Romsos D.R., Leveille G.A., Baker D.M., 1972. Lipogenesis and enzymatic activity in pig adipose tissue as influenced by source of dietary fat. J. Anim. Sci. 35, 41-47

Amstrong K.J., Stouffer J.F., Van Invegen R.G., Thompson W.J., Robison G.A., 1974. Effects of thyroid hormone deficiency on cyclic adenosine $3^{\prime}: 5^{\prime}$-monophosphate and control of lipolysis in fat cells. J. Biol. Chem. 249, 4226-4231

Awad A.B., Chattopadhyay J.P., 1986. Effect of dietary saturated fatty acids on hormone-sensitive lipolysis in rat adipocytes. J. Nutr. 116, 1088-1094

Beeb S.J., Redman J.B., Blackmore P.F., Corbin J.D., 1985. Discriminative insulin antagonism of stimulatory effects of various $\mathrm{c} \Lambda \mathrm{MP}$ analogs on adipocyte lipolysis and hepatocyte glycolysis. J. Biol. Chem. 260, 15781-15788 
Belfrage P., Fredrikson G., Nilsson N.O., Stralfors P., 1981. Regulation of adipose-tissue lipolysis by phosphorylation of hormone-sensitive lipasc. Int. J. Obes. 5, 635-641

Belfrage P., Fredrikson G., Stralfors P., I'ornquist H., 1984. Adipose tissue lipase. In: B. Borgstrom, H.L. Brockman (Editors). Lipase. Elsevier, Amsterdam, pp. 365-416

Bcnmansour N.M.M., Demame Y., Lecourtier M.J., Lhuillery C., 1991. Effects of dictary fat and adipose tissue location on insulin action in young boar adipocytes. Int. J. Biochem. 23, 499-508

Boll M., Weber L.W., Stampfl A., 1996. Nutritional regulation of the activities of lipogenic enzymes of rat liver and brown adiopose tissue. Z. Naturforsch. [C.] 51, 859-869

Butcher R.W., Braid C.E., Sutherland W.,1968. Effect of lipolytic and antylioplytic substances on adenosine 3'-5'-monophosphate levels in isolated fat cells. J. Biol. Chem. 243, 1705-1712

Campfield L.A., Smith F.J., Guisez Y., Devos R., Burn P.,1995. Recombinant mouse ob protein: Evidence for a peripheral signal linking adiposity and central neural networks. Science 269 , 546-549

Casanova L., Alonso G., Moreno F.J.,1990. Some aspects of metabolic adaptations in lipid metabolism during starvation are mimicked by epinephrine in rat adipocytes. Int. J. Biochem. 22, 19-23

Champigny O., Ricquier D., 1990. Effects of fasting and refeeding on the level of uncoupling protein mRNA in rat brown adipose tissue: evidence for diet-induced and cold-induced responses. J. Nutr. 120, 1730-1736

Degerman E., Landstrm T.R., Wijkander J., Holst L.S., 1998. Phosphorylation and activation of hormone-sensitive adipocyte phosphodicsterase type 3B. Methods 14, 43-53

Degerman E., Smith C.J., Tornqvist H., Vasta V.,Belfrage P., Manganielo V.C.,1990. Evidence that insulin and isoprenaline activate c(jMP inhibited low $\mathrm{K}_{\mathrm{m}}$, cAMP phosphodiesterase in rat fat cells by phosphorylation. Proc. Natl. Acad. Sci. USA, 874, 533-537

Ecke1 R.II., 1987. Adipose tissue lipoprotein lipase. In: I. Borensztang (Editor). Lipoprotein lipase. Evener, Chicago, pp. 79-132

Eriksson H., Ridderstråle M., Degerman E., T.kholm D., Smith C.J., Manganiello V.C., Belfrage P., Tomqvist H., 1995. Evidence for the key role of the adipocyte cGMP-inhibited cAMP phosphodicstcrasc in the antilipolytic action of insulin. Biochim. Biophys. Acta 1266, 101-107

Fickova M., Hubert P., Cremel G., Leray C., 1998. Dietary (n-3) and (n-6) polyunsaturated fatty acids rapidly modyfy fatty acid composition and insulin effects in rat adipocytes. J. Nutr. 128, 512-519

Field C.J., Ryan A., Thomson A.B.R., Clandinin M.T., 1988. Dictary fat and the diabetic state alter insulin binding and the fatty acid composition of the adipocyte plasma membrane. Biochem. $\mathrm{J}$. $253,417-424$

Field C.J., Ryan E.A., Thomson A.B., Clandinin M.T., 1990. Diet fat composition alters membrane phospholipid composition, insulin binding, and glucose metabolism in adipocytes from control and diabetic animals. J. Biol. Chem. 265, 11143-11150

Field C.J., Toyomizu M., Clandinin M.T., 1989. Relationship between dietary fat, adipocyte membrane composition and insulin binding in the rat. J. Nutr. 119, 1483-1489

Frederich R.C., Hamann A., Anderson S., Löllmann B., I owell B.B., Flier J.S., 1995a. I eptin levels reflect body lipid content in mice. Evidence for diet-induced resistance to leptin action. Nature Mcd. 1, 1311-1314

Frederich R.C., Löllmann B., Hamann A., Napolitano-Rosen A., Kahan B.B., Lowell B.B., Flier I.S., 1995b. Expression of $o b \mathrm{mRN} A$ and its encoded protein in rodents: Impact of nutrition and obesity. J. Clin. Investig. 95, 1658-1663

Fried S.K., Hill J.O., Nickel M., DiGirolamo M.,1983. Prolonged effects of fasting-refeeding on rat adipose tissue lipoprotein lipase activity: influence of caloric restriction during refecding. $J$. Nutr: 113, 1861-1869 
Gettys T.W., Harkness P.J., Watson P.M., 1996. The beta 3-adrenergic receptor inhibits insulinstimulated leptin secretion from isolated rat adipocytes. Endocrinology 137, 4054-4057

Gorman R.R., Tepperman H.M., Tepperman J.,1972. Effects of starvation, refeeding, and fat feeding on adipose ghost adenyl cyclase activity. J. Lipid Res.13, 276-280

Gould R.J., Ginsberg B.H., Spector A.A., 1982. Lipid effects on the binding properties of a reconstituted insulin receptor. J. Biol. Chem. 257, 477-484

Gries F.A., Berger M., Neumann M., Preiss H., Liebermeister H., Hesse-Wortmann C., Jahnke K., 1972. Fffect of norepinephrine, theophylline and dibutyryl cyclic AMP on in vitro lipolysis of human adipose tissue in obesity. Diabetologia $8,75-83$

Groscolas R., Herzberg G.R.,1997. Fasting-induced selective mobilization of brown adipose tissue fatty acids. J. Lipid Res. 38, 228-238

Hadri K.E., Charon C., Pairault J., Hauguel-De Mouzon S., Quignard-Boulange A., Feve B., 1997. Down-regulation of $\beta_{3}$-adrenergic receptor expression in rat adipose tissue during the fasted/ fed transition: evidence for a role of insulin. Biochem. J. 323, 359-364

Ip C., Tepperman H.M., Witt J.D., Tepperman J., 1977. The effect of diet fat on rat adipocyte glucose transport. Hormone Metab. Res. 9, 218-222

Jenkins T.C., Thies E.J., Fotouhi N.,1994. Dietary soybean oil changes lipolytic rate and composition of fatty acids in plasma membranes of ovine adipocytes. J. Nutr. 124, 566-570

Jeppesen J., Hollenbeck C.B., Zhou M.Y., Coulston A.M., Jones C., Chen I., Reaven G.M., 1995. Relation between insulin resistance, hyperinsulinemia, postheparin plasma lipoprotein lipase activity, and postprandial lipemia. Arteroscler. Thromb. Vasc. Biol.15, 320-324

Kenan Y., Levison M., l'ines M., Naim M.,1992. Differential post-receptor responses of adenylate cyclase in white and brown adipose tissue membranes of rats fed high-energy diets. Comp. Biochem. Physiol. Comp. Physiol.103, 823-826

Kenan Y., Levison M., Pines M., Naim M., 1997. Adenylyl cyclase inhibitory pathway is differentially modified in rat white and brown fat by high-energy diets. Amer. J. Physiol. 272, E1043 E1049

Kim J.B., Sarraf P., Wright M., Yao K.M., Mueller E., Solanes G., Lowell B.B., Spiegelman B.M., 1998. Nutritional and insulin regulation of fatty acid synthetase and leptin gene expresion through ADDl/SREBPI. J. Clin. Invest.101,1-9

Langin D., Ekholm D., Ridderstrale M., Lafontan M., Belfrage P., 1992. CAMP-dependent protein kinase activation mediated by $\beta_{3}$-adrenergic receptors parallels lipolysis in rat adipocytes. Biochim. Biophys. Acta 1135, 349-352

Lefebvre P.J., 1975. Commentary : glucagon and adipose tissue. Biochim. Pharmacol. 24, 1261-1266

L.to J., Rizkalla S.W., Boillot J., Alamowitch C., Chaib H., Bruxzo F., Desplanque N., Dalix A.M., Durand G., Slama G.,1996. Dietary (n-3) polyunsaturated fatly acids improve adipocyle insulin action and glucose metabolism in insulin resistant rats: relation to membrane fatty acids. J. Nutr. 126, 195]-1958

Maffei M., Fei H., Lee G.H., Dani C., Leroy P., Zhang Y., Proencea R., Negrel R., Ailhaud G., Friedman J.M., 1995a. Increased expression in adipocytes of $o b$ RNA in mice with lesions of the hypothalamus and with mutations at the $d b$ locus. Proc. Natl. Acad. Sci. USA 92, 6957-6960

Maffei M., Hallaas J., Ravussin E., Pratley R.E., Lee G.H., Zhang Y., Fei H., Kim S., Lallone R., Ranganathan S., Kern P.A., Friedman J.M., 1995b. Leptin levels in human and rodent measurement of plasma leptin and of RNA in obese and weight-reduced subjects. Nature Med. 1, 1155-1161

Matamala J.C., Gianotti M., Pericas J., Quevedo S., Roca P., Palou A., Garcia-Palmer F.J., 1996. Changes induced by fasting and dietetic obesity in themogenic parameters of rat brown adipose tissue mitochondrial subpopulations. Biochem. J. 319, 529-534 
Matsuo T., Shimomura Y., Saitoh S., Tokuyama K., Takeuchi H., Suzuki M., 1995. Sympathetic activity is lower in rats fed a beef tallow diet than in rats fed a safflower diet. Metabolism 44. 934-939

May J.M., Mikulecky D.C., 1983. Glucose utilization in rat adipocytes. The interaction of transport and metabolism as affected by insulin. J. Biol. Chem. 258, 4771-4777

Mersmann H.J., 1986. Acute effects of metabolic hormones in swinc. Comp. Biochem. Physiol. 83A, 653-660

Moriya M., 1994. Nutritional adaptation in brown adipose tissue thermogenesis - with special reference to overfeeding and iron deficiency. Hokkaido Igaku Zasshi 69, 1115-1131.

Mueller W.M., Gregoire F.M., Stanhope K.L., Mobbs C.V., Mizuno T.M., Warden C.H., Stern J.S., Havel P.J., 1998. Evidence that glucose metabolism regulates leptin secretion from cultured rat adipocytes. Endocrinology 139, 551-558

Muller G., Ertl J., Gerl M., Preibisch G.,1997. Leptin impairs metabolic actions of insulin in isolated rat adipocytes. J. Biol. Chcm. 272,10585-10593

Oka Y., Akanuma Y., Kasuga M., Kosaka K.,1980. Effect of a high glucose diet in insulin binding and insulin action in rat adipocytes. A longitudinal study. Diabetologia 19, 468-474

Olefsky J.M., Seakow M., 1978. The effects of dietary carbohydrate content on insulin binding and glucose metabolism by isolated rat adipocytes. Endocrinology 103, 2252-2263

Oudart H., Groscolas R., Calgari C., Nibbelink M., Leray C., I.e Maho Y., Malan A., 1997. Brown fat thermogenesis in rats fed high-fat dicts enriched with n-3 polyunsaturated latty acids. Int. $J$. Obes. Me1ab. Disord. 21, 955-962

Owens J.L., Thomson D., Shah V., DiGirolamo M., 1979. liffects of fasting and refeeding in the rat on adipocyte metabolic functions and response to insulin. J.Nutr. 109, 1584-1591

Parrish C.C., Myher J.J., Kuksis A., Angel A.,1997. Lipid structure of rat adipocyte plasma membranes following dietary and fish oil. Biochim. Biophys. Acta 1323, 253-262

Pcdersen O., Kahn C.R., Flier J.S., Kahn B.B., 1991. High fat feeding causes insulin resistance and a marked decrease in the expression of glucose transporters (Glut 4) in fat cells of rats. Endocrinology $129,771-777$

Perea A., Martinell C.J., Villanueva-Penacarillo M.L., Valverde I., 1995. Physiological effect of glucagon in human isolated adipocytes. Hormone Metab. Res. 27, 372-375

Rodbcll M.,1964. Metabolism of isolated fat cells. I. Effects of hormones on glucose metabolism and lipolysis. J. Biol. Chem. 239, 375-380

Rodbell M., Jones A.B., Chiappe de Cingolani G.E., Birnbaumer L., 1968. The actions of insulin and catabolic hormones on the plasma membrane of the fat cclls. Rec. Progr. Horm. Res. 24, 215-254

Rosen O.M.,1987. After insulin binds. Science 237, 1452-1458

Ruiz G., Sobrino F., Roca, Goberna R.,1981. Cyclic AMP-dependent protein kinase activity and lipolysis in adipose tissuc. Effect of fasting, oligomycin and iodoacetamide. Rev. Esp. Fisiol. $37,455-462$

Saladin R., de Vos P.. Guerre-Millo M., I eturgue A., Girard J., Staels B., Auwerx J., 1995. Transient incrcase in obese gene expression after food intake or insulin administration. Nature 377 , $527-529$

Salans L.B., Dougherty J.W., 1971. The effect of insulin upon glucose metabolism by adipocyte cells of different size. J. Clin. Investig. 50, 1399-1410

Sevilla L., Guma A., Fnrique-Tarancon G., Mora S., Munoz P., Palacin M., Testar X., Zorzano A., 1997. Chronic high-fat feeding and middle-aging reduce in an additive fashion Glut4 expression in skeletal muscle and adipose tissue. Biochem. Biophys. Res. Commun. 235, 89-93 
Slieker L.J., Sloop K.W., Surface P.L., Kriauciunas A., Laguier F., Manetta J., Buevaleskey J., Stephens T.W., 1996. Regulation of expression of $o b$ messenger-RNA and protein by glucocortycoids and cAMP. J. Biol. Chem. 271, 5301-5304

Smith D.R., Knabe D.A., Smith S.B., 1996. Depression of lipogenesis in swine adipose tissue by specific dietary fatty acids. J. Anim. Sci. 74, 975-983

Smith U., Kral J., Björntorp J., 1974. Influence of dietary fat and carbohydrate on the metabolism of adipocytes different sizes in the rat. Biochim. Biophys. Acta 337, 278-285

Stephens T.W., Basinski M., Bristow P.K., Bue-Valleskey J.M., Burgett S.G., Craft L., Iale J., I loffnann J., Hsiung H.M., Kriauciunas A., MacKellar W., Rosteck P.R., Schoner B., Smith D., Tinsley F.C., Zhang X.Y., Heyman M., 1995. The role of neuropeptide $Y$ in the antiobesity action of the obese gene product. Nature $377,530-532$

Stralfors P., Bjorgell P., Belfrage P., 1984. Hormonal regulation of hormone-sensitive lipase in intact adipocytes: identification of phosphorylated sites and effect on the phosphorylation by lipolytic hormones and insulin. Proc. Natl. Acad. Sci. USA 81, 3317-3321

Tebar F., Soley M., Ramircz I., 1996. The antilipolytic cffects of insulin and cpidermal growth factor in rat adipocytes are mediated by different mechanisms. Endocrinology 107, 4181-4188

Timmers K., Knittle J.L., 1980. Effects of undernutrition and refeeding on enzyme activities and rates of glucose catabolism in rat epididymal adipose tissue. J. Nutr. 110, 1176-1184

Tornqvist H.E., Pierce M.W., Frackelton A.R., Nemenoff R.A., Avruch J., 1987. Identification of insulin receptor tyrosine residues autophosphorylated in vitro. J. Biol. Chem. 262, 10212-10219

Van Amelsvoort J.M.M., Van der Beck A., Stam J.J., Houtsmuller U.M.T., 1988. Dietary influence on the insulin function in the epididymal fat cell of the Wistar rat. I. Effect of type of fat. Ann. Nutr. Metab. 32, 138-146

Walder K., Filippis A., Clark S., Zimmet P., Collier G.R., 1997. Leptin inhibits insulin binding in isolated rat adipocytes. J. Endocrinol.155, R5-R7

Wang Q., Bing C., AL-Barazanji K., Mossakowaska D.E., Wang X.M., McBay D.L., Neville W.A., Taddayon M., Pickavance L., Dryden S., Thomas M.E., McHale M.T., Gloyer I.S., Wilson S., Buckingham R., Arch J.R., Trajhurn P., Williams G., 1997. Interactions between leptin and hypothalamic neuropeptide $\mathrm{Y}$ neurons in the control of food intake and energy homeostasis in the rat. Diabetes 46, 335-341

Watarani T., Kobayashi M., Takata Y., Sasaoka T., Iwasaki M., ShigetaY., 1988. Alteration of insulin-receptor kinase activity by high fat feeding. Diabetes $37,1397-1404$

Wilding J.P.H., Gilbey S.G., Bailey C.J., Batt R.A.I., Williams G., Ghatei M.A., Bloom S.R., 1993. Increased neuropeptide $Y$ messenger ribonucleic acid (mRNA) and decreased neurotensin mRNA in the hypotalamus of the obese (ob/ob) mouse. Endocrinology 132, 1939-1944

Yu B.P., Bertrand H.A., Masoro E.J., 1980. Nutrition-aging of catecholaminepromoted lipolysis. Metabolism 29, 438-444

\section{STRESZCZENIE}

\section{Wpływ diety na przemiany tłuszezowe w komóree. Przegląd literatury}

W pracy krótko scharaktery/owano procesy zachodzące w adipocytach oraz przedstawiono regulacyjne działanie niektórych hormonów i czynników pochodzenia pokarmowego.

Adipocyty są komórkami białej tkanki thuszczowej magazynującymi znaczne ilości triglicerydów. Proces powstawania triglicerydów w tych komórkach zwany lipogenezą jest stymulowany 
przez insulinę. Natomiast lipoliza, czyli rozkład triglicerydów przebiegający z uwolnieniem glicerolu i wolnych kwasów thuszczowych do krwi jest nasilana przez glukagon i adrenalinę. Wiele czynników związanych z żywieniem takich jak na przykład głodzenie, stan odżywienia, ilość węglowodanów, ilość i skład tłuszczów mogą modyfikować te procesy.

Dieta i jej skład mają także istotny wpływ na brunatną tkankę tłuszczową. 